\title{
Study of Lapsi Fruits Enterprise Opportunities
}

\author{
Rinita Rajbhandari Joshi \\ Department of Science and Humanities, Institute of Engineering, Tribhuvan University, Nepal \\ Corresponding author:joshirinita@yahoo.com
}

Received: May 21, $2017 \quad$ Revised: Nov 10, $2017 \quad$ Accepted: Nov 15, 2017

\begin{abstract}
Choerospondias axillaris is locally known as Lapsi in Nepal. The study of enterprises of Lapsi fruits production and its uses in market was conducted in September, 2015 in Bhaktapur district and Kalimati Fruits and Vegetable Wholesale Market, Kathmandu, Nepal. The major objectives were to study Lapsi fruits enterprises and its uses in different sectors. Lapsi fruits are sold in wholesale and retail price in Kalimati Fruits and Vegetable Wholesale Market. In Bhaktapur, Lalitpur and Kathmandu districts, the production areas covered were 198.0, 15.0 and 55.0 hectare, total productions were 105.0,150.0 and 405.0 metric ton with productivity of $0.9,10.0$ and 7.4 metric ton per hectare respectively. The total Lapsi fruits production area, total production and productivity were 1503.0 hectare, 10488.0 metric ton and 7.4 metric ton per hectare in Nepal. The monthly maximum price of Lapsi fruits was NRs.30.00/kg in July/ August 2015. Similarly, the maximum price reached up to NRs.110.0 in February/March. The pulp of the Lapsi fruits is use preparing Lapsi powder, candy and it's seed stone can be use for the preparation of activated carbon. Government policies should be clear about increase in production and productivity by the help of subsidy inputs. Farm get price should be reasonable. Lapsi candy processing and activated carbon production industries should be promoted where Lapsi fruits are cultivated. Hygienic candy and activated carbon should be exported to neighboring countries and overseas. It helps to earn foreign currency and develop economic of the country.
\end{abstract}

Keywords: Lapsi fruits production, processing, candy product, marketing and consumers.

\section{Introduction}

Nepal is an agrarian country employing 65 percent of the economically active population. Agriculture is the main source of food, income and employment for majority of the population [3]. The share of horticulture in Agriculture Growth Domestic Product (AGDP) is 23 percent. Lapsi (Choerospondias axillaris) is grown in hills, $850-1900 \mathrm{~m}$. Lapsi trees are distributed from North - East India to South - East China, Japan, Assam, Sikkim, Vietnam, Thailand, Japan and Hongkong. Its tree is used for timber in China and for medical value in Vietnam [13]. Lapsi tree is largely known for its delicious fruits in Nepal. The pulp/peel of ripen/raw fruits are use for sweet and sour pickles and candies. The seeds are used for brick kilns[6]. Recent research on preparation of activated carbon by zinc chloride from Lapsi seed has shown the potential use for the adsorption of arsenic from water [11,12]. Lapsi fruits are very rich in essential amino 
acids, especially arginine (106 mg/100gm), glutamine acid (36 mg/100gm), glutamine (36 gm/100 $\mathrm{gm})$, vitamin $\mathrm{C}$ and minerals such as potassium $(355 \mathrm{mg} / 100 \mathrm{gm})$, calcium $(57 \mathrm{mg} / 100 \mathrm{gm})$ and magnesium (34 mg/100gm) [10].Lapsi has been recognized as one of the potential agro-forestry tree species for income generation to hill farming communities in Nepal $[8,9]$.

\section{Literature Review}

Government of Nepal has emphasized on the production and processing of such high value agro forestry product (APP, 1995). Lapsi fruits cultivation and commercial enterprises can improve the income of farmers and thus, contribute in poverty reduction [5].Government of Nepal, Ministry of Agriculture Development in collaboration with Federation of Nepal Chamber of Commerce (FNCCI) has initiated One Village One Product (OVOP) program of Lapsi fruits in Bhaktapur. Kalimati Fruits and Vegetable Wholesale Market was set up by the then Department of Food and Agriculture Marketing Services under Ministry of Agriculture in 1996. Kalimati Fruits and Vegetable Market is the pioneer organized terminal and first established wholesale market in Nepal. .

Bhaktapur Municipality (Changunarayan) is very popular for lapsi fruits production. Champak Candy Industry was established in 2012 and is located in Bhaktapur. The industry purchases Lapsi fruits for candy processing from local growers. Champak Candy Industry produces many varieties of Lapsi candy. The products of Lapsi candy have a good market in Kathmandu valley as well as out of countries [4]. Kalimati fruits and vegetables whole sale market is an access for whole sellers, retailers, producers, farmers, middle men and consumer. The market helps to meet demands and spplies of product by farmers which can be purchased by consumers [7].

\section{Material and Methods}

Kalimati Fruits and Vegetables Whole Sale Market and Bhaktapur (Changunarayan) district were purposively selected for this study based on coverage area of Lapsi growers, production, availability of processing small scale industries, marketing value and its use by consumers. forty respondents were selected for comparing growers, contractors, middlemen, processors, retailers, wholesalers and consumers. Pre - tested interview schedule, key informant interview, group discussion, primary and secondary data and literatures were collected from government organizations and others institutions. Final collected information was analyzed by the help of SPSS and was also interpreted on paper.

\section{Result and Discussion}

\subsection{Lapsi Fruits Production in Nepal}

Lapsi fruits are delicious and very popular in Nepali culture. Lapsi fruits can be consumed before and after annual processing. Lapsi fruits production is increasing according to demand of consumers in market. Thirty two districts have been producing Lapsi fruits in Nepal. Bhojpur district is one of the highest producers and its total production was 2106.0 metric ton of Lapsi fruits on an area of 390.0 hectare. In case of Bhaktapur, Lalitpur and Kathmandu districts, the production areas covered were 198.0, 15.0 and 55.0 hectare, total productions were 105.0, 150.0 and 405.0 metric ton with productivity of $0.9,10.0$ and 7.4 metric ton per hectare respectively. The total Lapsi fruits production area, total production and productivity were 1503.0 hectare, 10488.0 metric ton and 7.4 metric ton per hectare in Nepal (Table 1). 
Table 1: Lapsi fruits Covered Area, Production Area and Productivity in Nepal, 2014

\begin{tabular}{|c|c|r|r|r|r|}
\hline S.N & District & $\begin{array}{c}\text { Covered } \\
\text { Area (Ha) }\end{array}$ & $\begin{array}{c}\text { Production } \\
\text { Area (Ha) }\end{array}$ & \multicolumn{1}{c|}{$\begin{array}{c}\text { Production } \\
\text { (Mt) }\end{array}$} & $\begin{array}{c}\text { Productivity } \\
\text { (Mt /Ha) }\end{array}$ \\
\hline 1 & Taplejung & 50 & 30 & 165 & 5.5 \\
\hline \multicolumn{2}{r|}{ Eastern Mountain } & $\mathbf{5 0}$ & $\mathbf{3 0}$ & $\mathbf{1 6 5}$ & $\mathbf{5 . 5}$ \\
\hline
\end{tabular}

\begin{tabular}{|c|c|c|c|c|c|}
\hline 2 & Ilam & 2 & 0 & 0 & 0 \\
\hline 3 & Terhathum & 120 & 120 & 648 & 5.4 \\
\hline 4 & Dhankuta & 210 & 210 & 1134 & 5.4 \\
\hline 5 & Bhojpur & 390 & 390 & 2106 & 5.4 \\
\hline 6 & Khotang & 2 & 1 & 5 & 5 \\
\hline 7 & Okhaldhunga & 11 & 10 & 60 & 6 \\
\hline 8 & Eastern Hill & 735 & 731 & 3953 & 5.44 \\
\hline \multicolumn{2}{|c|}{ Eastern Development Region } & 785 & 761 & 4118 & 5.47 \\
\hline 9 & Dolakha & 50 & 44 & 308 & 7 \\
\hline 10 & Sindhupalchok & 350 & 272 & 3264 & 12 \\
\hline 11 & Rasuwa & 2 & 0 & 0 & 0 \\
\hline 12 & Mid Mountain Area & 402 & 316 & 3572 & 9.5 \\
\hline 13 & Ramechhap & 53 & 31 & 298.8 & 9.6 \\
\hline 14 & Kavreplanchok & 65 & 57 & 456 & 8 \\
\hline 15 & Bhaktapur & 198 & 120 & 105.6 & 9.0 \\
\hline 16 & Lalitpur & 15 & 15 & 150 & 10 \\
\hline 17 & Kathmandu & 92 & 55 & 405 & 7.4 \\
\hline 18 & Nuwakot & 25 & 15 & 165 & 11 \\
\hline 19 & Makwanpur & 11 & 7 & 46 & 6.6 \\
\hline 20 & Mid Hill Area & 459 & 300 & 1626.4 & 7.6 \\
\hline \multicolumn{2}{|c|}{ Central Development Region } & 861 & 616 & 5198.4 & 8.6 \\
\hline 21 & Lamjung & 17 & 4 & 15 & 3.8 \\
\hline 22 & Tanahu & 2 & 2 & 15 & 7.5 \\
\hline 23 & Kaski & 30 & 20 & 160 & 8 \\
\hline 24 & Parbat & 122 & 65 & 800 & 12.3 \\
\hline 25 & Syangja & 148 & 24 & 105 & 4.4 \\
\hline 26 & Myagdi & 0.2 & 0.1 & 1 & 10 \\
\hline 27 & Baglung & 1 & 0 & 0 & 0 \\
\hline 28 & Gulmi & 6 & 5 & 30 & 6 \\
\hline 29 & Western Hill & 326.2 & 120.1 & 1126 & 7.4 \\
\hline \multicolumn{2}{|c|}{ Western Development Region } & 326.2 & 120.1 & 1126 & 7.4 \\
\hline 30 & Achham & 3 & 1 & 9.5 & 9.5 \\
\hline 31 & Baitadi & 1 & 0.5 & 3.5 & 7 \\
\hline
\end{tabular}




\begin{tabular}{|c|c|r|r|r|r|}
\hline 32 & Dadeldhura & 4 & 4 & 32.8 & 8.2 \\
\hline Far Western Hill & $\mathbf{8}$ & $\mathbf{5 . 5}$ & $\mathbf{4 5 . 8}$ & $\mathbf{8 . 2}$ \\
\hline Far Western Development Region & $\mathbf{8}$ & $\mathbf{5 . 5}$ & $\mathbf{4 5 . 8}$ & $\mathbf{8 . 2}$ \\
\hline Nepal & 1980.2 & 1502.6 & 10488.2 & 7.4 \\
\hline
\end{tabular}

Source: Fruit Development Directorate, Kritipur2014

\subsection{Supply Source of Lapsi Fruits}

Fig. 1 shows that nine districts were main sources of supply of Lapsi fruits to wholesalers in Kalimati Fruit and Vegetable Market. Kathmandu district was the main supply source of Lapsi fruits in wholesale price in Kalimati Fruit and Vegetable Market. In 2014, Kathamandu district supplied $38915.0 \mathrm{~kg}$ of Lapsi Fruit to the Wholesale Market. In 2014, the total supply of Lapsi fruits was 68.43 metric ton which was used in marketing for human consumption in different aspects. In 2015, supply of Lapsi fruits from Kathmandu district to wholesale price in Kalimati Fruit and Vegetable Market was 20.0 metric ton. Lapsi fruits supply was comparatively low in 2015 may be its supply to market and Lapsi growing areas were affected by earth quake in 2015 .

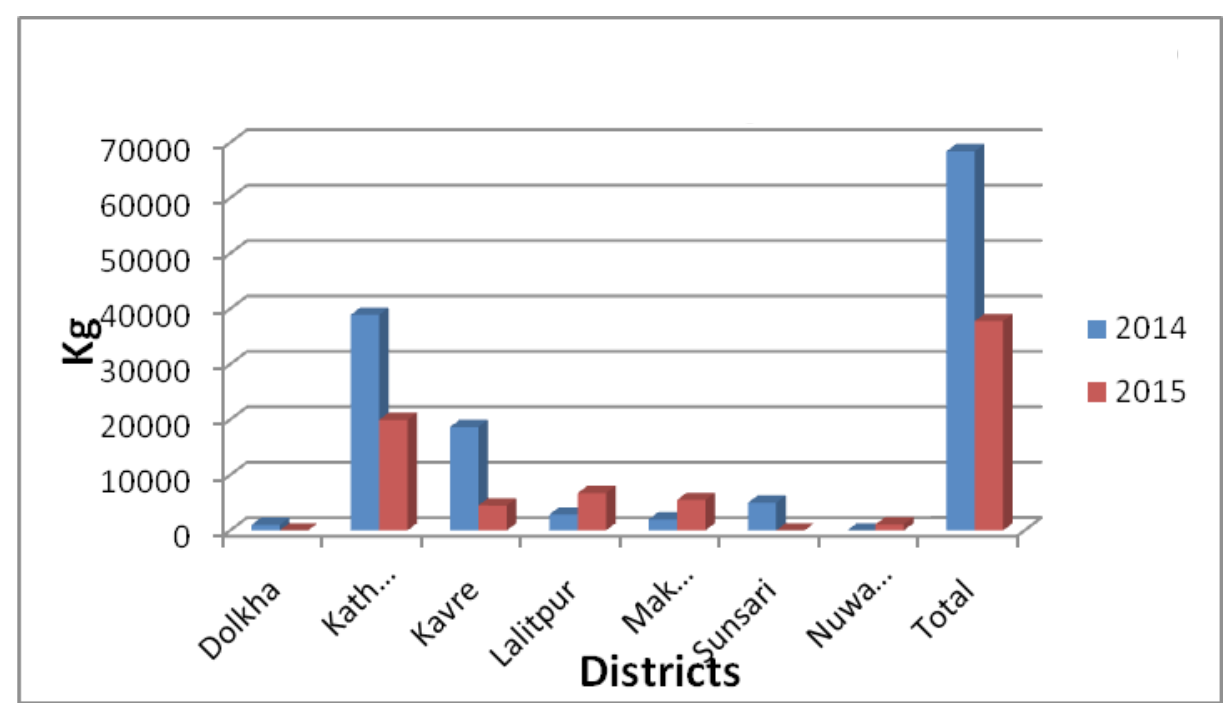

Fig.1: Supply source of Lapsi fruits from different districts to Kalimati Fruit and Vegetables Market

Source: 1. Annual Publication (2014) Kalimati Fruits \& Vegetable Wholesale Market [1] 2. Annual Publication (2015) Kalimati Fruits \& Vegetable Wholesale Market [2]

\subsection{Lapsi Fruits Transaction and Price in Kalimati Fruit and Vegetable Wholesale Market}

Kalimati Fruits and Vegetable Wholesale Market has one of the highest quantity transactions of Lapsi fruits according to consumer demand. Lapsi fruits is available in the market from July/ August to March/April. In 2014, the average monthly price of Lapsi fruits was NRs.21.15/kg in July/August, However, the price increased to NRs.24.0/kg in July/August 2015. The monthly maximum price of Lapsi Fruits was NRs.30.00/kg in July/ August 2015. Similarly, the maximum price reached up to NRs.110.0 in February/March and $6450.0 \mathrm{~kg}$ of Lapsi Fruit was sold as supplementary fruits according to the need of consumers (Table 2). 
Table 2: Lapsi Fruit Monthly Transactions, Average Monthly Price, Minimum Price and Maximum Price in Kalimati Fruit and Vegetable Wholesale Price Market, 2014 - 2015.

\begin{tabular}{|c|c|c|c|c|c|c|c|c|c|}
\hline \multirow[t]{2}{*}{ S.N } & \multirow[t]{2}{*}{ Month } & \multicolumn{2}{|c|}{ Transaction (Kg) } & \multicolumn{2}{|c|}{$\begin{array}{l}\text { Average Monthly } \\
\text { Price, NRs/Kg }\end{array}$} & \multicolumn{2}{|c|}{$\begin{array}{c}\text { Monthly } \\
\text { Minimum Price, } \\
\text { NRs/Kg }\end{array}$} & \multicolumn{2}{|c|}{$\begin{array}{l}\text { Monthly Maximum } \\
\text { Price, NRs/Kg }\end{array}$} \\
\hline & & 2014 & 2015 & 2014 & 2015 & 2014 & 2015 & 2014 & 2015 \\
\hline 1 & July/August & 0 & 0 & 21.15 & 24.00 & 18.00 & 18.00 & 25.00 & 30.00 \\
\hline 2 & $\begin{array}{c}\text { August/ } \\
\text { Sept }\end{array}$ & 2555 & 5450 & 24.00 & 25.00 & 18.00 & 18.00 & 30.00 & 32.00 \\
\hline 3 & Sept/Oct & 22165 & 10400 & 25.00 & 25.00 & 20.00 & 18.00 & 30.00 & 32.00 \\
\hline 4 & Oct/Nov & 16255 & 5200 & 28.28 & 37.50 & 24.00 & 25.00 & 35.00 & 50.00 \\
\hline 5 & Nov/Dec & 17075 & 5200 & 29.16 & 31.50 & 25.00 & 28.00 & 35.00 & 35.00 \\
\hline 6 & Dec/Jan & 10930 & 4500 & 33.41 & 33.00 & 26.00 & 28.00 & 40.00 & 55.00 \\
\hline 7 & Jan/Feb & 9015 & 8020 & 44.71 & 80.00 & 30.00 & 40.00 & 60.00 & 120.00 \\
\hline 8 & Feb/March & 1800 & 6450 & 98.18 & 105.00 & 55.00 & 100.00 & 120.00 & 110.00 \\
\hline 9 & $\begin{array}{c}\text { March/ } \\
\text { April }\end{array}$ & 0 & 0 & 124.26 & 136.50 & 110.00 & 0 & 130.00 & 0 \\
\hline & Total & 79795 & 45220 & Av.47.53 & Av.55.28 & Av.18.00 & 0 & Av.130.00 & Av. 120.00 \\
\hline
\end{tabular}

Source: Annual Publication (2014) Kalimati Fruit \& Vegetable Wholesale Market.

\subsection{Lapsi Fruits Transaction Trend in Kalimati Fruit and Vegetable Wholesale Market}

Transaction trends of Lapsi Fruit and its annual average price from 2010 to 2015 were analyzed in Kalimati Fruit and Vegetable Wholesale Market. The annual transaction of Lapsi Fruit increased from 26200.0 to $79795.0 \mathrm{~kg}$ and the annual average price increased from 34.98 to 47.53 between 2010 and 2014. However, transactions of Lapsi Fruits decreased in 2015, may be it was affected by earth quake and thus, the Lapsi fruit growers could not access transportation and management in Kalimati Wholesale Market (Table 3).

Table 3: Lapsi Fruits Transaction Trend and Annual Average Price in Kalimati Fruit and Vegetable Wholesale Market, 2010-2015

\begin{tabular}{|c|c|c|c|c|c|c|}
\hline \multirow{2}{*}{ S.N } & \multicolumn{7}{|c|}{ Year } \\
\cline { 2 - 7 } & 2010 & 2011 & 2012 & 2013 & 2014 & 2015 \\
\hline Quantity, kg & 26200.00 & 72000.00 & 63415.00 & 79760.00 & 79795.00 & 45220.00 \\
\hline $\begin{array}{c}\text { Annual average } \\
\text { price, NRs./kg }\end{array}$ & 34.98 & 27.94 & 34.18 & 51.57 & 47.53 & 55.28 \\
\hline
\end{tabular}

Source: Annual Publication (2015) Kalimati Fruit \& Vegetable Wholesale Market.

Fig. 2 shows that collectors, middlemen and entrepreneurs have collected Lapsi fruits from different growers of Bhaktapur (Changunarayan, VDC) district. Lapsi fruist was transacted in Kalimati Fruits and Vegetables Market through different market channels. Lapsi fruits are sold in wholesale and retail price in Kalimati Fruits and Vegetable Wholesale Market. Consumers use Lapsi fruits from Kalimati Market for different purpose like Achar (pickle) mixed with cucumber, 
radish, carrot, green chilli and pea. Lapsi candy is made by processing Lapsi and the candy can be use for a year. There are many varieties of candies which can be exported to South Asian Regional Countries. It can help to earn foreign currency and generate employment opportunity.

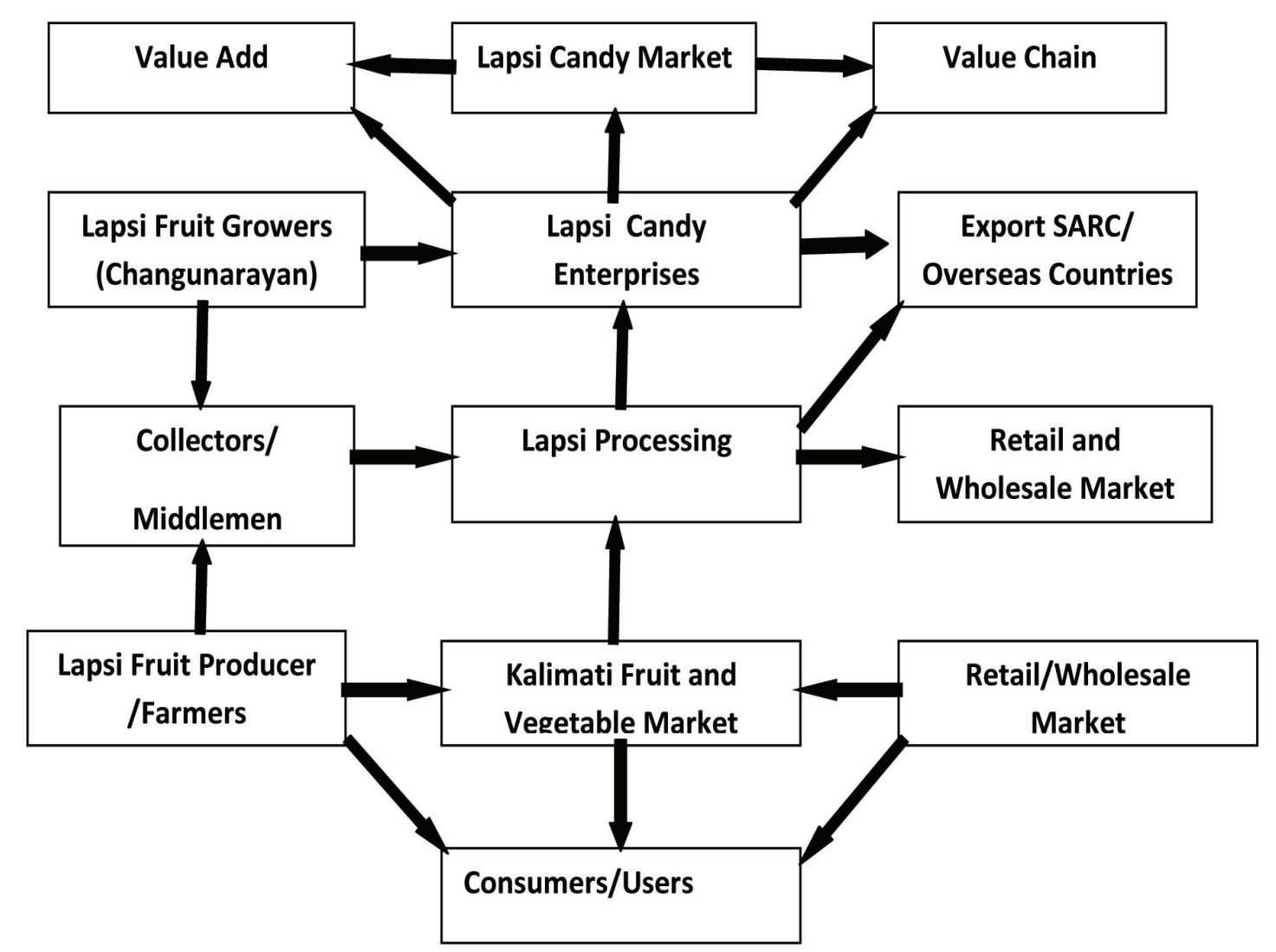

Fig. 2: Lapsi Fruits Growers, Enterprises and Market Channel

\subsection{Lapsi Candy Processing, Products and Uses}

Champak Lapsi Candy products are supplied to markets as demanded by consumers. The supply markets are local Bhaktapur, Bhaktapur Durbar square, Bhaktapur commercial industry and Lalitpur and Kathmandu trade centers. Champak Lapsi candy products have good internal and external markets. There were more than eight varieties of Lapsi candies. The varieties of Lapsi candies and their wholesale prices are candy masla of NRs $210.0 / \mathrm{kg}$, candy red of NRs. $210.0 /$ $\mathrm{kg}$, black candy of NRs $190.0 / \mathrm{kg}$, long dry candy of NRs. $190.0 / \mathrm{kg}$, round candy of NRs. $220.0 /$ $\mathrm{kg}$, block candy of 190.0/kg, chatpat candy of NRs. $190.0 / \mathrm{kg}$ and soup candy of NRs. $135.0 / \mathrm{kg}$ respectively. 


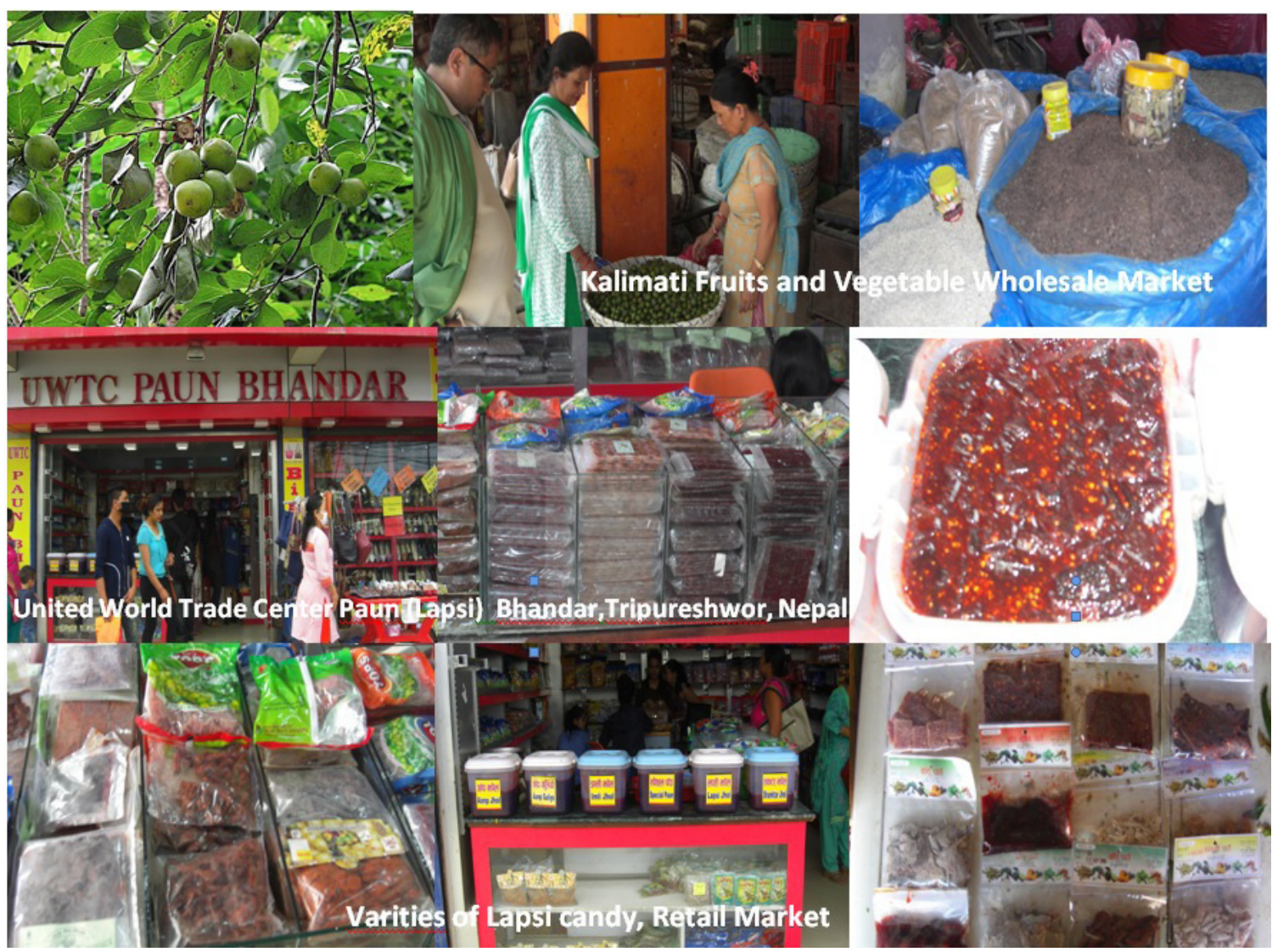

Fig. 3: Photos of Lapsi and Candy, Kathmandu

\section{Conclusion and Recommendation}

Lapsi is a delicious fruit which is supplementary food for humans and it support in food digestion. Lapsi fruits are sold in wholesale and retail price in Kalimati Fruits and Vegetable Wholesale Market. Lapsi fruits are available in the market from July/August to March/April. Consumers purchase Lapsi fruits from Kalimati Market and local market for different uses like making pickle. Lapsi pickle is mostly available in Nepalese kitchen. Lapsi candy is made by processing pulp of Lapsi which can be used for a year. Lapsi candy is also use as souvenir for non residential Nepalese people. Its demand is increasing day by day. Recent research has shown the Lapsi seed as a source for the preparation of activated carbon. Production of Lapsi fruits should be increased to more than 12.0 ton per hectare. Government policies should be clear to increase its production and productivity with the help of subsidy inputs. Farm get price should be reasonable as well. Candy processing industries should be promoted where Lapsi fruits are cultivated. Hygienic Lapsi candies should be export as it helps to earn foreign currency and promotes economic development of Nepal.

Production of Lapsi fruits should be increased to more than 12.0 ton per hectare. Research on improved varieties of Lapsi fruits should be promoted through Nepal Agricultural Research Council (NARC). Lapsi cultivation should be extensively and intensively done in the pocket area. Consumer's price and farm get price of Lapsi fruits should be reasonable at harvesting time for 
growers. Pre harvest and post harvest training should be provided to Lapsi fruits growers. Candy products of Lapsi fruits should have quality and quantity. Government policies should be clear to facilitate Lapsi fruits candy producers with loan of minimum interest. Candy products should be increased for export in neighboring countries and overseas. This will earn foreign currency and help to generate employment as well.

\section{References}

[1] Annual Publication (2014), Kalimati Fruits \& Vegetable Wholesale Market 2014 Development Samittee, Kalimati Kathmandu, Nepal.

[2] Annual Publication (2015), Kalimati Fruits \& Vegetable Wholesale Market 2014 Development Samittee, Kalimati Kathmandu, Nepal.

[3] CBS (2010), Statistical pocket book of Nepal. Government of Nepal, National Planning Commission Secretariat, Central Bureau of Statistics, Ramshahpath, Thapathali, Kathmandu, Nepal, P 210.

[4] Champak Lapsi Candy Product Industry (2015), Candy Product Industry, Bhaktapur, District, Nepal,

[5] FDD (2014), Bagbani Bikash Karyakram, Fruit Development Directorate, Kirtipur, Kathmandu, Nepal.

[6] Gautam KH (1997), The sweet and sour tale of Lapsi - Domesticating and Commercializing Choerosponding axillaris. Agroforestry Today 9 (3): 13 - 16.

[7] Joshi KR, Shrestha B and Amatya SM (2008), A case Study of Kalimati Fruits and Vegetables Market and its Price Situation. The Fifth National Conference on Science and Technology, P436, Nepal.

[8] LARC (1997), The Strategy for agro-forestry research. Lumle agricultural research team LARC strategy paper No. 97/3, Lumle Agricultural Research Center, Kaski, Nepal.

[9] Paudel KC and Parajuli DP (1999), Domestication and Commercialization of Lapsi tree: Scientific World 1(1): 116 - 120. Ministry of Science and Technology, Kathmandu, Nepal.

[10] Paudel KC, Eder R, Paar E and Pieber K (2002), Chemical composition of Lapsi (Choerospondias axillaries) fruits from Nepal. J. Mitteilungen Klosterncuburg, $52: 42-53$.

[11] Rajbhandari R, Shrestha LK and Pradhanaga RR (2011), Preparation of Activated Carbon from Lapsi Seed Stone and its Application for the Removal of Arsenic from Water, Journal of Institute of Engineering, Nepal, 8: 211-218.

[12] Rajbhandari R, Shrestha LK and Pradhanaga RR (2012), Nanoporous Activated Carbon Derived from Lapsi (Choerospondias Axillaris) Seed Stone for the Removal of Arsenic from Water, Journal of Nanoscience and Nanotechnology, 12 : 7002-7009.

[13] Roxburgh, W. (1832). Fl.Ind.Ed2: 453.S 